\title{
Game-based learning: Reinforcing a paradigm transition on pedagogy amid COVID-19 to complement emergency online education
}

\author{
Cathy Mae Dabi Toquero ${ }^{1}$, Dalj Andrew Sonsona ${ }^{1}$ and Karen Joy B. Talidong ${ }^{2}$ \\ ${ }^{1}$ Mindanao State University-General Santos City, Philippines; ${ }^{2}$ Shaanxi Normal University, Xi'an, China
}

\begin{abstract}
As classes transitioned to the emergency online learning environments, teachers are confronted with pedagogic challenges, particularly on ways to stimulate the curiosity, creativity, and critical thinking of the students. To address this challenging scenario, the application of game-based learning can equip the teachers with pedagogical advantage to supplement their instruction in the experimentum crusis of emergency online teaching amid the global health emergency. This article can give insights to the educators relative to the benefits of game-based learning to uplift the skills of digital learners during the worldwide transition to digital learning during the COVID-19 and post-pandemic era. Higher education can incorporate game-based pedagogy during their virtual classes. It recommends a strengthening of the utilization of game-based learning to further deliver authentic learning to meet the needs of the learners despite the pandemic, without compromising the health and safety of the learners. The authors are hoping that eventually, the game-based vantage point can inspire educators for a paradigm transition from conventional classes and online technological experiments to a learner-centered online learning environment in the post-pandemic world.
\end{abstract}

Keywords: COVID-19, online learning, game-based learning, emergency remote teaching, emergency online teaching, game pedagogy

\section{Introduction}

The COVID-19 pandemic challenged governments around the world and have initiated protocols such as lockdown and physical distancing (Gonzalez et al. 2020) that required educational institutions to venture into the virtual realms. The severe short-term disruption is felt by many families around the world: homeschooling is not only a massive shock to parents' productivity but also children's social life and learning. The closures of the educational institution due to the outbreak of COVID-19 lead to an unprecedented impact on education; teaching is moving online on an untested and unprecedented scale; student assessments are also moving online - with a lot of trial and error and uncertainty for everyone. In truth, these interruptions will not just be a short-term issue, but can also have a long-term consequence for the affected cohorts and are likely to increase inequality.

COVID-19 severely affects the whole world, including the education sector as $90 \%$ of school closures took place (Toquero, 2020) and staggering death cases are in the charts. Governments' efforts to support learning amidst the pandemic produce new ways of educational learning that do not compromise the learner's health. Nonetheless, the challenges continue to appear. Students

\section{Address of Corresponding Author}

Cathy Mae D. Toquero, College of Education, Mindanao State University, General Santos City, 9500, Philippines.

$\triangle$ cathymaetoquero@gmail.com

0000-0002-6044-6771

How to cite: Toquero, C. M. D., Sonsona, D. A., \& Talidong, K. J. B. (2021). Game-based learning: reinforcing a paradigm transition on pedagogy amid COVID-19 to complement emergency online education. International Journal of Didactical Studies 2(2), 101458. https:/ / doi.org/10.33902/ IJODS.2021269730 
are consumed with problems such as interconnectivity and inadequacy of technologies, and unpreparedness to suffice the new learning.

Given the abrupt changes in education due to COVID-19, higher education encounters tremendous challenges with the proper implementation of educational responses (Sutton \& Jorge, 2020; Toquero, 2020; Strielkowski, 2020) to continue through distance education (Bozkurt, 2019) despite the spread of COVID-19. Part of the efforts raised in institutions of higher learning include homeschooling and working at home. Educational institutions went to remote operation and engaged in emergency remote teaching (Bozkurt \& Sharma, 2020) as a transition process from the conventional classrooms. The considerations for an inevitable change of fate in the education sector (Affouneh, Salha, \& Khlaif, 2020; Basilaia \& Kvavadze, 2020; Guo et al., 2020; Klapproth et al., 2020) include various problems that are associated with equality in education, quality instruction, technical skills of teachers, and students' motivation to learn. Apart from these realities, COVID-19 heightens issues on unequal access to technologies (Lynch, 2020) since both teachers and learners 'forcedly' shifted to emergency online instruction (Talidong \& Toquero, 2021).

The integration of computers, smartphones, and other devices in the teaching and learning process is a move that every school must embrace to become relevant in the present time (Barrera, Jaminal \& Arcilla Jr., 2020). Additionally, various online platforms further utilize the essence of the technology. However, these efforts of the government - particularly in the educational sector, face several loopholes in the derivation of the immediate shift of learning. Teacher training, socio-economic and socio-cultural aspects, and technological adoption are crucial elements in student learning. There should be considerations in the socio-economic capability of every institution. In the Philippine context, there are places that technology is not able to reach - these are the remote areas that are in the mountain-side communities. Toquero (2021) emphasized that the inadequacy in technological equipment and the failure to consider socio-cultural aspects could hinder technological adoption. The lack of technological devices and intermittent connections may hinder the students in taking advantage of learning opportunities. These identified loopholes lead the way to modular distance learning, wherein it involves individualized instruction that allows learners to use Self-Learning Modules (SLMs) in print format.

Consequently, the governments, together with the educational organizations need to deal with the digital divides and social inequities (Toquero, Calago, \& Pormento, 2021) that students and teachers may face relative to maintaining the equality in education and the quality of teachers despite under pressure. The provision of moral and logistical support is crucial to continue emergency e-learning. Apart from the digital divide and educational inequity (Bozkurt, 2020; Moore, Vitale \& Stawinoga, 2018; Samar, Nagwa, Hany, Cliff, Noha, Mohamed \& Abdulmonem, 2020) during this crisis, however, one of the most important factors to learning retention such as student motivation remains a challenge in instruction. Lack of exposure to the real world while learning through technology due to distancing protocols may create impediments (Toquero et al., 2021) for the teachers to create meaningful learning.

Despite the challenges in these unprecedented times, there are opportunities in the fourth industrial revolution. Based on a study, digital learning can still improve the learning outcome of the students and ameliorate the capabilities of educators (Abdulrahim \& Mabrouk, 2020) in virtual classrooms. Evidently, it is still impossible for the teachers to become online experts, especially during this emergency when everything presents a hallmark for challenging circumstances.

Nevertheless, it is significant to feed the students' learning with spices that could stimulate their minds to digest learning. This idea means that emergency e-learning instruction should be more interesting and innovative to motivate the students to learn remotely (Blass \& Hayward, 2014; Shan, 2015). The transition to e-learning thereby is an opportunity for instructors to capture the attention of digital students through game-based learning (Cózar-Gutiérrez \& SáezLópez, 2016). Hence, this study significantly offers the teachers and students during this global health emergency to experience active engagements during the shift to emergency online education.

\section{Game-Based Learning and the Concept of Games}

A widespread number of studies conducted on game-based learning provide different definitions of games in instruction. Game-based learning does not literally refer to the game. It is a system of instruction governed by rules and quantifiable outcomes (Pho \& Dinscore, 2015; Plass, Homer, \& Kinzer, 2015; Al Fatta, Maksom, \& Zakaria, 2019). It is a constructed activity that resembles 
portions of reality (Ariffin \& Alan Oxley, 2014) with a set of gamified elements or game mechanics that are applied to a non-game setting (Brown et al., 2018; Lengyel, 2020). Moreover, technological devices and software are incorporated in the concept of games which present the idea of digital game-based learning (Brown et al., 2018; Lengyel, 2020; Talib et al., 2019).

Likewise, game-based learning awakens the students' curiosity, competitiveness, and creative behaviors that enable them to construct concepts (Boyle, 2011). Game-based learning has already been found to be useful in Mathematics (Ferguson, 2014; Logan, 2020; Brezovszky, et al., 2019), which could also be integrated into English (Hung, 2018), and other subjects.

The secret ingredient is the creativity of the instructors on how to design game-based instruction that would fit the level and interests of their students (Puentedura, 2012). Apart from the risks in face-to-face instruction, the traditional method of teaching is not as beneficial for motivating students to learn (Al-Azawi, Al-Faliti, \& Al-Blushi, 2016). Furthermore, game-based education is already practiced in higher education (Campos, Nogal, Caliz, \& Juan, 2020) that stimulates the teaching and learning process, allowing state-of-the-art teaching methodologies that help the students enrich their learning experiences.

To integrate games as an educational tool, however, it is pertinent to develop models to produce high-quality games. The models can ensure educational value, game-play design, and appropriateness to the target students (Hollins, 2011). Educational institutions should train the teachers and future teachers in teacher-training programs to learn games and facilitation techniques (Sardone, 2018). By doing so, they can develop assessments and design strategies built on game content.

\section{Game-Based Learning and 21 st Century Pedagogy}

Game-based learning presents potential benefits to the learning outcomes for students to acquire 21st-century skills despite the pandemic. COVID-19 posed a challenge for all education sectors worldwide. However, access to education and social status are crucial factors to consider among education administrators and government agencies (Affouneh et al., 2020). Given the necessary learning tools, game-based learning can offer an opportunity to develop motivation and experiential learning among students (Sutton \& Jorge, 2020) albeit the full deployment of technology during this crisis.

Studies showed that the use of game-based learning might improve student-learning outcomes (Brezovszky, 2019; Wardoyo, DwiSatrio, \& Ma'ruf, 2020). Digital games had certain advantages and values for cognitive memory-based learning (Wu et al., 2020). Specifically, students with a higher level of inner motivation and positive attitude towards GBL are more likely to have higher learning expectations, and to experience more satisfaction in their GBL participation (Vlachopoulos and Makri, 2017), whereas indicates better engagement towards the learning of the students (Auman, 2011). Further, the educational benefits of game-based learning are particularly apparent in subjects over which students report greater anxiety, where it can be proven that increased enjoyment levels are positively associated with better learning and higher-order thinking skills (Crocco et al., 2016). Likewise, as a way to examine game-based learning for instruction, many studies have revealed the significant effects of game-based learning in developing 21st-century skills among students (Qian \& Clark, 2016; Perrotta, Featherstone, Aston, \& Houghton, 2013; Al Fatta, Maksom, \& Zakaria, 2019; Ariffin \& Alan Oxley, 2014).

Considering that game-based learning became popularized along with the presence of technological equipment and devices, it has been implemented in many settings including workplace training, education, and social media (Pho \& Dinscore, 2015). Pertaining to the education domain, the pedagogical shift and increased use of games as innovative technology need to be transformed in higher education. In this respect, it is predicted that games and simulations will play an important role in the learning process and will be pivotal in the global health crisis (Vlachopoulos \& Makri, 2017).

Much literature existed on game-based learning in terms of pedagogical instruction, revealing its relevance in the field of education. The pieces of literature that are identified differ in courses or subjects, yet present significant findings of game-based learning. The study conducted by Talib et al. (2019) suggested that game-based learning should be integrated into engineering and technology courses to enhance reasoning skills for better productivity. Game-based learning provides an opportunity for the students to acquire sets of skills like critical thinking, reasoning, and problem-solving skills to help them achieve the specific learning goals (Talib et al., 2019). The game pedagogy benefits the students to analyze situations, organize data and information, set a goal, and construct different patterns and designs. These skills are identified as the most essential skills that an engineering and technology student needs (Talib et al, 2019). In addition, the 
researchers (Talib et al., 2019) identified various games from existing pieces of literature that record the essential roles and indicate how games can be integrated into the teaching and learning of engineering and technology courses. The games include Scratch, Puzzle, Simulation, Video Game, Kahoot, and Brain Blast.

Games anchored in the real-life learning environment of learners must be one of the criteria in determining its effectiveness as an educational tool. In this sense, Lengyel (2020) explored the teaching-learning environment of accounting concepts in the virtual classroom by preparing learning materials combined with gamified elements. The researcher utilized the LMS (Learning Management System) e-learning platform that is the Moodle (Modular Object-Oriented Dynamic Learning Environment) to create a virtual classroom. She included games, crossword puzzles, word puzzles, and quizzes in lessons to measure the performance of her students in the accounting lessons. She also designed a game that consisted of the parts of accounting - available in Accounting Basics E-Book (Lengyel, 2020).

Additionally, the Meta-Analysis carried by Wu et al. (2020) acknowledged that digital games played a significant role in promoting English vocabulary learning. By analyzing and summarizing the studies according to the five influencing factors laid by the researchers namely: the learning stage, game-aided teaching method, native language background, game platform, and game scenario, they suggested that continuous optimization of games-based teaching and learning must be done. They also added that it is necessary to improve game-based mechanisms to further attract students learning motivation. Their view of game-based learning concludes possible applications in reading and writing of the English concepts (Wu et al., 2020). It allows the learners to train cognitively with the advanced skills that are present in the interactive features of digital games.

According to Eltahir et al. (2021), the utilization of games-based learning resulted in a significant improvement in the students' engagement, motivation, and academic performance in an Arabic language course. It is evident in their conducted case study which consists of the control group $(n=53)$ that was instructed using a non-game-based method; and the other an empiric group $(n=54)$ that used the game-based classroom response system. Researchers' results revealed that there were statistical differences in the benefit of the empirical group. They showed improved knowledge of the concepts taught in the Arabic language grammar course with higher motivation than the students in the control group.

Moreover, Taub et al. (2019) investigated the effect of agency on students' learning, problemsolving behaviors, emotions, and engagement (i.e., presence, interest) while interacting with a game-based learning environment that fosters Self-Regulated Learning and scientific reasoning while being presented information about microbiology. In this study, the agency was defined as the degree of freedom and control that is afforded to a player to perform meaningful actions in a virtual environment (Wardrip-Fruin, Mateas, Dow, \& Sali, 2009). The researchers revealed their findings in the study. Firstly, the time spent in a game was significantly different among the agency conditions in the study. The result is primarily due to the structure of the Agency Conditions. Different time duration plays important implications, as Low Agency and No Agency conditions were given an increased amount of time than the High Agency conditions. Secondly, the amount of learning observed was significantly different among the different agency conditions, with the Low Agency condition achieving the largest normalized learning gain scores. It is evident in the conducted independent two-sample t-test which showed students in the Low Agency condition had marginally higher normalized learning gains than students in the High Agency condition $(\mathrm{t}(81)=1.76, \mathrm{p}=0.082, \mathrm{~d}=0.35)$, and significantly higher normalized learning gains than students in the No Agency condition $(t(64)=3.13, p<0.01, d=0.76)$. The remaining test has proved that students belonging to the High Agency condition have marginally better normalized learning gains than those students in the No Agency condition $(\mathrm{t}(60)=1.81, \mathrm{p}=0.076, \mathrm{~d}=0.39)$. Lastly, results revealed differences in emotion and engagement outcomes among agency conditions, but surprisingly no distinguishable differences between the High Agency and Low Agency conditions were observed. No Agency condition reported significantly lower presence and interest with the game-based learning environment. This implies that students who were given no agency had the lowest amounts of all affective responses. The results demonstrate that the level of agency can be important for impacting learning gain and performance, but providing any type of agency (compared to no agency) is beneficial for engagement and interest. Therefore, it appears that degree of agency can have a different impact on different types of actions or behaviors (Taub et al., 2019).

In addition to the foregoing discussions, the systematic review administrated by Brown et al. (2018) supported the idea that games (i.e. digital and non-digital) can supplement and 
complement traditional methods of teaching styles in the field of science in higher education. Despite the barriers hindering the development of utilizing games in instructions, the researchers identified resources to diminish further conflicts regarding the development of games in academic instructions.

\section{Teacher Supervision and Feedback}

In every learning structure, teachers can be more efficient and effective when they are able to incorporate the instructional design features of the teaching approach and strategies. Additionally, the principles of game-based learning guide the implementation of the teachers in pedagogical instruction. The concepts of games used in education must include: 1) learning principles, 2) student engagement, 3) learning opportunities, 4) 21st-century skills development, and; 5) authentic and relevant assessment (Al-Azawi, Al-Faliti, \& Al-Blushi, 2016).

Concerning the role of the teachers, they can give feedback, and guide the students who have difficulty in proceeding to the next level (Sutton \& Jorge, 2020). Even though emergency remote teaching is lenient and temporary (Hodges, Moore, Lockee, Trust \& Bond, 2020), teachers still need the training to strengthen their pedagogy for virtual classes (Bhaumik \& Priyadarshini, 2020) during this crisis. It is still vital to consider the principles of game-based learning as an approach. Teachers, however, should bear in mind the responsiveness, relevance, and sustainability in learning in its application in pedagogical instruction.

\section{Emerging Technologies as Platforms during the Emergency}

Game-based learning can provide a platform for students to develop their emotional intelligence skills through different sets of games (Almeida, 2020). Designing well-crafted games for any instruction challenges the students to think critically. Since they have to set a goal for winning, the teachers should supervise that simultaneously, pedagogical activities through games can be cooperative for all students. Through this kind of approach, students can be able to improve their self-confidence. Their curiosity to discover the answers to a problem and eagerness to proceed to the next level promotes goal-oriented students. As a result, students can be reflective and be motivated to do the tasks needed to reach their goals.

The current emergency online teaching scenario shows no difference from traditional teaching, except for the integration of technology. Game-based learning, however, stimulates logical thinking among students if appropriately implemented. Through games conducted online delivered through Zoom, Google Meet, Skype, and other complementary tools such as social media or videoconferencing platforms, students can find learning fun, exciting, and worthwhile. This game pedagogy is an instructional shift away from the usual inactive online classroom environment delivered through long hours of online lectures.

\section{Conclusion and Recommendations}

The education sector, with the assistance of government interventions, can support academic continuity despite the crisis. The continuing application of technological modalities is part and parcel of the new normal and next normal era in the education system. However, challenges in student engagement and motivation in the online environment persist. Thus, it is advantageous for the teachers to strengthen the application of game-based learning in educational delivery. Through the portals of digital technology, students should continue to have fun and engage in the trial-and-error process of acquiring knowledge. Teachers should attempt to ensure that in-depth learning prevails in emergency remote teaching or emergency online learning environments. The principles of game-based learning can stimulate the interest of the students in learning. This innovation is contrary to the conventional delivery of instructional plans where the students remain passive and unengaged. The research on games and game-based learning highlights significant research on its effectiveness in delivering instructions in different academic domains. The studies indicate that the learners can acquire benefits such as motivation, competence to learn in new ways, skills that are essential in real-life environments, and many more. Though relatively limited to only systematic reviews, meta-analyses, and open access journals, the concept of game-based learning is highlighted as having a significant role in improving learners to learn, particularly in this time of remote emergency education. Teachers, thereby, need to suffice the development of the students' skills through internalizing, applying, and studying the concepts of game-based learning. This helps improve their instruction from mere lectures to interactive digital engagement among the students. Hence, different stakeholders in the education sector and government agencies should support the value of experiential and effective learning among the 
students through digital game-based learning during this pandemic and after COVID-19. Teachers need training on how to make their teaching strategies more learner-centered using game-based learning as an approach. Future research can examine the application of game-based learning in enhancing student learning during emergency remote teaching and evaluate the effectiveness of this approach in developing the students' cognitive, behavioral, and emotional engagement post-pandemic.

\section{References}

Al-Azawi, R., Al-Faliti, F., \& Al-Blushi, M. (2016). Educational gamification vs. game-based learning: comparative study. International Journal of Innovation, Management and Technology, 7(4), 132-136.

Abdulrahim, H., \& Mabrouk, F. (2020). COVID-19 and the digital transformation of Saudi Higher Education. Asian Journal of Distance Education, 15(1), 291-306. https://doi.org/10.5281/zenodo.3895768

Affouneh, S., Salha, S., \& Khlaif, Z. N. (2020). Designing quality e-learning environments for emergency remote teaching in coronavirus crisis. Interdisciplinary Journal of Virtual Learning in Medical Sciences, 11(2), 135-137. https://doi.org/10.30476/ijvlms.2020.86120.1033

Almeida, F. (2020). Adoption of a serious game in the developing of emotional intelligence skills. European Journal of Investigation in Health, Psychology and Education, 10(1), 30-43.

Ariffin, M. M., Oxley, A., \& Sulaiman, S. (2014). Evaluating game-based learning effectiveness in higher education. Procedia-Social and Behavioral Sciences, 123, 20-27.

Auman, C. (2011). Using simulation games to increase student and instructor engagement. College Teaching, 59(4), 154-161.

Barrera, K. I., Jaminal, B., Arcilla, F., (2020). Readiness for flexible learning amidst COVID-19 pandemic of Saint Michael College of Caraga, Philippines. SMCC Teacher Education Journal, 2, 1-15. https://dx.doi.org/10.18868/cte.02.060120.01

Basilaia, G., \& Kvavadze, D. (2020). Transition to online education in schools during a SARS-CoV-2 coronavirus (COVID-19) pandemic in Georgia. Pedagogical Research, 5(4), em0060.

Bhaumik, R., \& Priyadarshini, A. (2020). E-readiness of senior secondary school learners to online learning transition amid COVID-19 lockdown. Asian Journal of Distance Education, 15(1), 244-256. https://doi.org/ 10.5281/zenodo.3891822

Blass, E., \& Hayward, P. (2014). Innovation in higher education; will there be a role for "the academe/university" in 2025? European Journal of Futures Research, 2(1), 1-9.

Boyle, S. (2011, October). An Introduction to Games based learning. https://www.ucd.ie/t4cms/UCDTLT0044.pdf.pdf

Brezovszky, B., McMullen, J., Veermans, K., M.Hannula-Sormunen, M., Rodríguez-Aflecht, G., Pongsakdi, N., . . Lehtinen, E. (2019). Effects of a mathematics game-based learning environment on primary school students' adaptive number knowledge. Computers and Education, 128, 63-74. https://doi.org/10.1016/j.compedu.2018.09.011

Bozkurt, A. (2019). From distance education to open and distance learning: A holistic evaluation of history, definitions, and theories. In S. Sisman-Ugur (Ed.) Handbook of Research on Learning in the Age of Transhumanism (pp. 252-273). IGI Global. https://doi.org/10.4018/978-1-5225-8431-5.ch016

Bozkurt, A., \& Sharma, R. C. (2020). Emergency remote teaching in a time of global crisis due to CoronaVirus pandemic. Asian Journal of Distance Education, 15(1). https://doi.org/10.5281/zenodo.3778083

Bozkurt, A., Jung, I., Xiao, J., Vladimirschi, V., Schuwer,...\& Paskevicius, M. (2020). A global outlook to the interruption of education due to COVID-19 pandemic: Navigating in a time of uncertainty and crisis. Asian Journal of Distance Education, 15(1), 1-126. https://doi.org/ 10.5281/zenodo.3878572

Brown, C, L., Comunale, M. A., Wigdahl, B., \& Urdaneta-Hartmann, S. (2018). Current climate for digital game-based learning of science in further and higher education. FEMS Microbiology Letters, 365(21), fny237. https://doi.org/10.1093/femsle/fny237

Campos, N., Nogal, M., Caliz, C., \& Juan, A. A. (2020). Simulation-based education involving online and oncampus models in different European universities. International Journal of Educational Technology in Higher Education, 17(1), 1-15.

Cózar-Gutiérrez, R., \& Sáez-López, J. M. (2016). Game-based learning and gamification in initial teacher training in the social sciences: an experiment with MinecraftEdu. Technology in Higher Education, 13(2), $1-11$.

Crocco, F., Offenholley, K., \& Hernandez, C. (2016). A proof-of-concept study of game-based learning in higher education. Simulation \& Gaming, 47(4), 403-422 (2016). https://doi.org/1046878116632484 
Eltahir, M.E., Alsalhi, N.R., Al-Qatawneh, S., AlQudah, H.A., \& Jaradat, M. (2021). The impact of gamebased learning (GBL) on students' motivation, engagement and academic performance on an Arabic language grammar course in higher education. Educ Inf Technol, 26, 3251-3278. https://doi.org/10.1007/s10639-020-10396-w

Al Fatta, H., Maksom, Z., \& Zakaria, M. H. (2019). Game-based learning and gamification: Searching for definitions. International Journal of Simulation: Systems, Science \& Technology, 19, 10-5013.

Ferguson, T. L. (2014). Mathematics achievement with digital game-based learning in high school algebra 1 classes. https://pdfs.semanticscholar.org/7391/32d9b92ff81872f7e23f78d679e86294fedd.pdf

Gonzalez, T., De La Rubia, M. A., Hincz, K. P., Comas-Lopez, M., Subirats, L., Fort, S., \& Sacha, G. M. (2020). Influence of COVID-19 confinement on students' performance in higher education. PloS one, 15(10), e0239490.

Guo, J., Huang, F., Lou, Y., \& Chen, S. (2020). Students' perceptions of using mobile technologies in informal English learning during the COVID-19 epidemic: A study in Chinese rural secondary schools. Journal of Pedagogical Research, 4(4), 475-483. https://doi.org/10.33902/JPR.2020063786

Hodges, C., Moore, S., Lockee, B., Trust, T., \& Bond, A. (2020). The difference between emergency remote teaching and online learning. Educause Review, 27, 1-12.

Hollins, P. (2011). From the games industry: Ten lessons for game-based learning. International Journal of Virtual and Personal Learning Environments, 2(2), 73-82. https://doi.org/10.4018/jvple.2011040107

Hung, H.-T. (2018). Gamifying the flipped classroom using game-based learning materials. ELT Journal, 72(3), 296-308.

Klapproth, F., Federkeil, L., Heinschke, F., \& Jungmann, T. (2020). Teachers' experiences of stress and their coping strategies during COVID-19 induced distance teaching. Journal of Pedagogical Research, 4(4), 444452. https://doi.org/10.33902/JPR.2020062805

Lengyel, P. S. (2020). Can the game-based learning come? Virtual classroom in higher education of $21 \mathrm{st}$ century. International Journal of Emerging Technologies in Learning, 15(2). https://doi.org/10.3991/ijet.v15i02.11521

Logan, S. (2020). Essay on game based learning in mathematics specifically in using Bingo Game. https://www.essaytyping.com/essay-on-game-based-learning-in-mathematics-specifically-in-usingbingo-game/

Lynch, M. (2020). E-Learning during a global pandemic. Asian Journal of Distance Education, 15(1), $189-195$. https:/ / doi.org/10.5281/zenodo.3881785

Moore, R., Vitale, D., \& Stawinoga, N. (2018) The Digital Divide and Educational Equity: A look at students with very limited access to electronic devices at home. Insights in Education and Work. ACT Center for Equity in Learning.

Qian, M., \& Clark, K. (2016). Game-based Learning and 21st century skills: A review of recent research. Computers in Human Behavior, 63, 50-58.

Perrotta, C., Featherstone, G., Aston, H., \& Houghton, E. (2013). Game-based learning: latest evidence and future directions. Slough: NFER Research Programme: Innovation in Education.

Pho, A., \& Dinscore, A. (2015). Game-based learning. Tips and Trends. https://acrl.ala.org/IS/wpcontent/uploads/2014/05/spring2015.pdf

Plass, J. L., Homer, B. D., \& Kinzer, C. K. (2015). Foundations of Game-Based Learning. Educational Psychologist, 50(4), 258-283.

Puentedura, R. R. (2012). Game-Based Learning. https://hippasus.com

Ahmed, S. A., Hegazy, N. N., Malak, H. W. A., Kayser, W. C., Elrafie, N. M., Hassanien, M., ... \& Shehata, M. H. (2020). Model for utilizing distance learning post COVID-19 using (PACT) ${ }^{\mathrm{TM}}$ a cross sectional qualitative study. BMC Medical Education, 20(1), 1-13.

Sardone, N. (2018). Attitudes toward game adoption: Preservice teachers consider game-based teaching and learning. International Journal of Game-Based Learning, 8(3), 1-14. https://doi.org/10.4018/IJGBL.2018070101

Shan, L. G. (2015). The Benefits Of Game-Based Learning. https://leaderonomics.com/functional/benefitsof-gbl

Strielkowski, W. (2020). COVID-19 pandemic and the digital revolution in academia and higher education. Preprints.

Sutton, M. J., \& Jorge, C. F. (2020). Potential for radical change in Higher Education learning spaces after the pandemic. Journal of Applied Learning \& Teaching, 3(1), 1-5.

Talib, C. A., Aliyu, F., bin Abdul Malik, A. M., \& Siang, K. H. (2019). Enhancing students' reasoning skills in engineering and technology through game-based learning. International Journal of Emerging Technologies in Learning, 14(24), 69-80. https://doi.org/10.3991/ijet.v14i24.12117 
Talidong, K. J. B., \& Toquero, C. M. D. (2021). Facing COVID-19 through emergency online education anchored in Khan's framework: Case of Philippine teachers in Xi'an, China. European Journal of Interactive Multimedia and Education, 2(1), e02104. https://doi.org/10.30935/ejimed/9683

Taub, M., Sawyer, R., Smith, A., Rowe, J. Azevedo, R. \& Lester, J. (2019). The agency effect: The impact of student agency on learning, emotions, and problem-solving behaviors in a game-based learning environment. Computers \& Education, 147, 103781. https://doi.org/10.1016/j.compedu.2019.103781

Toquero, C. M. (2020). Challenges and opportunities for higher education amid the COVID-19 pandemic: The Philippine context. Pedagogical Research, 5(4), em0063.

Toquero, C. M. (2021). Experimento de educación remota de emergencia en medio de la pandemia de COVID19 en instituciones de aprendizaje en Filipinas. International Journal of Educational Research and Innovation, 15, 162-176. https://doi.org/10.46661/ijeri.5113

Toquero, C. M. D., Calago, P. A., \& Pormento, S. B. (2021). Neoliberalism crisis and the pitfalls and glories in emergency remote education. Asian Journal of Distance Education, 16(1), 90-97. https://doi.org/10.5281/zenodo.4672777

Vlachopoulos, D., \& Makri, A. (2017). The effect of games and simulations on higher education: a systematic literature review. International Journal of Educational Technology in Higher Education, 14(1), 1-33. https://doi.org/10.1186/s41239-017-0062-1

Wardrip-Fruin, N., Mateas, M., Dow, S., \& Sali, S. (2009) Agency reconsidered. http:/ / citeseerx.ist.psu.edu/viewdoc/download?doi=10.1.1.190.1393\&rep=rep1\&type=pdf

Wardoyo, C., DwiSatrio, Y., \& Ma'ruf, D. (2020). Effectiveness of game-based learning-learning in modern education. In G. Agustin (Ed.) 3rd International Research Conference on Economics and Business (pp. 8187). KnE Social Sciences. https://doi.org/10.18502/kss.v4i7.6844

Wu, Q., Zhang, J., \& Wang, C. (2020). The effect of English vocabulary learning with digital games and its influencing factors based on the meta-analysis of 2,160 test samples. International Journal of Emerging Technologies in Learning, 15(17), 85-100. https://doi.org/10.3991/ijet.v15i17.11758 